JURNAL PENDIDIKAN, p-ISSN 2715-095X, e-ISSN 2686-5041

Volume 30, No.1, Maret 2021 (105-112)

Online: http://journal.univetbantara.ac.id/index.php/jp

\title{
Peningkatan Kualitas Pembelajaran Guru Kelas V dan VI melalui Pembimbingan Partisipasi Aktif Kepala Sekolah di SD Negeri 2 Jobokuto Jepara
}

\author{
Siti Mahmudah \\ Kepala Sekolah SD Negeri 2 Jobokuto Kabupaten Jepara Jawa Tengah, \\ email:sitimahmudah290869@gmail.com
}

\begin{abstract}
Abstrak: Hasil pemantauan yang dilakukan oleh penulis menunjukkan kualitas proses pembelajaran guru kelas V dan VI SD Negeri 2 Jobokuto kurang maksimal. Rata-rata skor untuk guru kelas $\mathrm{V}$ adalah 1,12 dan guru kelas VI adalah 1,18 dengan rerata 1,15 dengan maksimal skor 3. Penelitian bertujuan untuk mengetahui peningkatan, kenaikan persentase dan efektivitas proses pembelajaran dengan bimbingan partisipasi aktif oleh kepala sekolah bagi guru kelas tinggi yaitu kelas V dan kelas VI SD Negeri 2 Jobokuto Kecamatan Jepara Kabupaten Jepara tahun pelajaran 2019/2020. Penelitian dilakukan dengan jenis metode Penelitian Tindakan Sekolah. Prosedur tindakan dilakukan meliputi dua siklus dan setiap siklus melalui 4 tahap yakni perencanaan, pelaksanaan, observasi, dan refleksi. Subjek penelitiaan guru kelas tinggi kelas V dan VI SD Negeri Jobokuto. Berdasarkan hasil pengamatan melalui bimbingan partisipasi aktif oleh kepala sekolah ada peningkatan kualitasproses pembelajaran dari kondisi awal ke siklus II yaitu dari 1,15 dapat dilaksanakan sangat efektif.
\end{abstract}

Kata-kata Kunci: Kualitas pembelajaran, pembimbingan, partisipasi aktif

\section{Improving Quality of Class V and VI Teacher Learning through Guidance for Active Participation of Principals at Elementary School}

\author{
Siti Mahmudah \\ Head Master of SD Negeri 2 Jobokuto Jepara Regency Central of Java \\ email:sitimahmudah290869@gmail.com
}

\begin{abstract}
The results of monitoring conducted by the author show that the quality of the learning process for the fifth and sixth grade teachers of SD Negeri 2 Jobokuto is not optimal. The average score for grade V teachers was 1.12 and class VI teachers were 1.18 with a mean of 1.15 with a maximum score of 3 . The research aims to determine the increase, increase in percentage and effectiveness of the learning process with active participation guidance by the principal for High class teachers, namely grade V and grade VI SD Negeri 2 Jobokuto, Jepara District, Jepara Regency in the 2019/2020 school year. The research was conducted with the type of School Action Research method. The action procedure is carried out covering two cycles and each cycle through 4 stages, namely planning, implementing, observing, and reflecting. The research subjects were grade V and VI grade teachers of SD Negeri Jobokuto. Based on the results of observations through active participation guidance by the principal, there was an increase in the quality of the learning process from the initial conditions to cycle II, namely from 1.15 it could be implemented very effectively.
\end{abstract}


Keywords: Quality of learning, guidance, active participation

\section{Pendahuluan}

Pemantauan kepala sekolah terhadap proses pembelajaran dikelas yang dilakukan guru, menunjukkan hasil proses pembelajaran yang belum optimal. Hal tersebut dibuktikan hasil pemantauan kondisi awal untuk guru kelas $\mathrm{V}$ diperoleh rerata 1,12 dan guru kelas VI memperoleh rerata 1,15 skor maksimalnya 3 . Hasil observasi selama supervisi terlihat bahwa: (1) secara umum guru melakukan proses pembelajaran menerapkan metode ceramah dengan melihat buku teks; (2) tujuan pembelajaran belum sesuai dengan yang diharapkan; (3) interaksi antar siswa belum tampak; (4)Penggunaan alat peraga belum obtimal; (5) guru belum menggunakan multi media komputer; dan (7) RPP (Rencana Pelaksanaan Pembelajaran) belum sesuai dengan strategi yang digunakan. Berdasarkan faktor-foktor di atas perlu adanya pembimbingan secara individu secara intensif, agar guru dapat merefleksi diri baik kekurangan dan kelemahan dalam kegiatan pembelajaran. kualitas pembelajaran. Juliantoro (2017:36) menjelaskan bahwa kualitas pendidikan di sekolah atau madarah harus diperhatikan dan ditingkatkan menjadi lebih baik dan berkualitas. Untuk mengatasi permasalahan di atas penulis berusaha meningkatkan dengan menggunakan pendekatan dengan partisipasi aktif, penulis peneliti dan guru berkumpul bersatu padu bekerja bersama-sama. Penulis meberikan contoh RPP sesuai dengan standar proses dengan harapan kualitas pembelajaran guru khususnya guru kelas V dan VI meningkat. Jika kemampuan guru dalam pembelajaran ini meningkat. Pembelajaran yang berkualitas juga diharapkan berdampak kepada prestasi belajar siswa. Senada dengan hasil penelitian Kholis dkk (2014: 139) menjelaskan pola pengembangan sekolah berkualitas dan budaya partisipasi di sekolahnya dapat digambarkan sebagai rumah. Kepala sekolah mempunyai peran yang sangat penting sebagai pondasi dominan menempati posisi sebagai pondasi, semakin kuat suatu pondasi semakin kuat bangunan rumah tersebut.

Sekolah dasar yang berkualitas adalah sekolah dasar yang mampu berfungsi sebagai wadah proses edukasi, wadah proses sosialisasi, dan proses transformasi, sehingga mampu mengantarkan peserta didik menjadi seorang terdidik, memiliki kedewasaan mental dan sosial, serta memiliki ilmu pengetahuan dan teknologi, termasuk juga kebudayaan bangsa. Salah satu komponen yang menentukan kualitas pendidikan adalah proses belajar mengajar atau pembelajaran (Bafadal, 2003:20). Unsur-unsur dalam pembelajaran meliputi unsur manusiawi, material, fasilitas, perlengkapan, dan prosedur yang saling berpengaruh untuk mencapai tujuan pembelajaran. Unsur manusia meliputi peserta didik, guru, dan tenaga kependidikan. Unsur material meliputi buku, papan tulis, , fotografi, kapur, audio dan video tape, slide dan film. Fasilitas yang harus terpenuhi antara lain ruang kelas, perlengkapan alat audio visual, dan komputer. Prosedur pelaksanaan meliputi penyusunan jadwal, metode, strategi dan alat evaluasi (Hamalik, 2001: 57). Sejalan dengan pengertian pembelajaran di atas, dikatakan oleh Arikunto (1993: 217) bahwa: (1) guru, konteks, siswa, kurikulum, metode, dan sarana adalah unsur yang dapat berpengaruh terhadap kualitas pembelajaran, (2) guru merupakan satu-satunya unsur yang mampu mengubah unsur yang lain menjadi bervariasi, sebaliknya unsur yang lain tidak dapat mengubah guru menjadi bervariasi, dan (3) guru merupakan unsur yang mempunyai peran amat penting bagi terwujudnya pembelajaran, menurut kualitas yang dikehendaki. Lalu, bagaimanakah pembelajaran disebut berkualitas atau berkualitas? Menurut Hamalik (2001:85), pembelajaran sebaiknya berdasarkan pada: (1) asas-asas belajar, (2) aktifitas 
belajar/keterlibatan langsung, (3) perbedaan individual, (4) pengulangan dan latihan, dan (5) adanya interksi dengan lingkungan. Kegiatan pembelajaran dapat dilakukan guru dengan mengacu pada standar nasional pendidikan yang ditentukan oleh Permendiknas Nomor 41 tahun 2007. Dalam melakukan proses pembelajaran tersebut, perlu ada kepala sekolahan oleh kepala sekolah yang terdiri dari pemantauan dan supervisi. Proses pembelajaran berkualitas meliputi perencanaan pelaksanaan, penilaian hasil pembelajaran dan peran kepala sekolahan. Seorang pembimbing tidak harus memiliki kepribadian khusus. Apapun kepribadian pembimbing, yang terpenting harus ada kepedulian terhadap orang yang akan dibimbing dan adanya kemauan mengembangkan wilayah yang ditangani (Cullen, 2004:13). Menurutnya, seorang pembimbing diharuskan:1) memunculkan kredibilitas, yaitu kejujuran, kompeten, inspirasi, dan visi; 2) mengatur dan mengemukakan tujuan dan harapan; 3) memiliki rencana agar berhasil; 4) memunculkan kinerja diri dan mempermudah pekerjaan; 5) memberi contoh; dan 6) memotivasi, membangun moral dan melakukan hubungan interpersonal. Selain itu seorang pembimbing perlu memperhatikan: (1) azaz manfaat, yaitu keberadaan pembimbing harus benar-benar bermanfaat maka pembimbing harus menguasai hal-hal yang berhubungan langsung dengan KBM dan dapat memberi contoh secara teknis maupun fisik, serta adanya keinginan kuat untuk membantu; (2) menumbuhakan sikap untuk menghargai usaha dan hasil kerja orang lain, dengan cara menunjukkan upaya dan hasil kerja yang sudah baik; (3) tidak terkesan menggurui, sikap tersebut diwujudkan dengan sikap membimbing atau mengajak seseorang untuk belajar menemukan sendiri alternatif-alternatif untuk memperbaiki kekurangannya dan kesalahan, serta menghindari penggunaan kalimat yang bersifat memaksa seperti: sebaiknya begini, tidak boleh begitu dan sebagainya; dan (4) komunikatif, hal tersebut bermakna bahwa proses pembimbingan harus berlangsung dua arah serta memberikan kesempatan lebih besar kepada yang dibimbing untuk mengemukakan buah pikirannya (Depdiknas, 1993: 13-14).

Partisipasi aktif dalam pelaksanakan bimbingan guru dalam meningkatkan kualitas pembelajaran sangat penting. Hal ini dijelaskan oleh (Syahyuti, 2014; 4) partisipasi adalah sebagai proses di mana seluruh pihak dapat membentuk dan terlibat dalam seluruhinisiatif. Partisipasi mempunyai nilai positip sisi positif 9program yang dijalankan akan lebih respon terhadap kebutuhan dasar yang sesungguhnya dan merupakan suatu cara penting untuk menjamin keberlanjutan program akan lebih efisien karena membantu mengidentifikasi strategi dan teknik yang lebih tepat. Selain itu bahwa partisipasi dengan fokus kepada keterlibatan aktif dari perilaku utama (primaty stekholders), maka tidak hanya akan dapat mengukur secara tepat keefektifan proyek, namun juga untuk terbangunnya rasa memiliki dan pemberdayaan untuk pihak penerima (beneficiaries), membangun akuntabilitas dan transparansi, dan mengambil peran untuk berjalannya proses yang tepat untuk meningkatkan kinerja dan hasil. Selain pendapat di atas tentang pentingnya partisipasi, Hagemann (1993:126) juga berpendapat bahwa partisipasi dapat meningkatkan komitmen orang dan mengurangi keinginan untuk membantah. Partisipasi dalam setiap persoalan yang terjadi berarti suatu kesempatan untuk realisasi diri. Jika kebutuhan manusiawi ini terpenuhi seseorang akan termotivasi. Partisipasi juga obat mujarab untuk konflik, mengingat kebanyakan konflik sebenarnya hanyalah reaksi menentang atas perasaan tidak senang.

Berdasarkan uraian fakta di atas yang menjadi permasalahan sebagai berikut: (1) Bagaimanakah pelaksanaan pembelajaran guru melalui pembimbingan partisipasi aktif oleh kepala sekolah Semester 1 SD Negeri 2 Jobokuto Kecamatan Jepara Kabupaten Jepara Tahun Pelajaran 2019/2020? (2)Berapa banyak persentase peningkatan pembelajaran bagi 
guru kelas V dan kelas VI Semester 1 SD Negeri 2 Jobokuto Kecamatan Jepara Kabupaten Jepara Tahun Pelajaran 2019/2020? dan (3)Bagaimanakah efektifitas pembimbingan guru melalui partisipasi aktif dari kepala sekolah dalam meningkatkan pembelajaran guru kelas V dan VI Semester 1 SD Negeri 2 Jobokuto Kecamatan Jepara Kabupaten Jepara Tahun Pelajaran 2019/2020?. Kaitanya dengan permasalahan di atas tujuan yang diharapkan adalah: (1) untuk mengetahui pelaksanaan pembelajaran guru kelas V dan guru kelas VI Semester 1 SD Negeri 2 Jobokuto Kecamatan Jepara Kabupaten Jepara Tahun Pelajaran 2019/2020 melalui pembimbingan partisipasi aktif oleh kepala sekolah, (2) untuk mengetahui seberapa banyak persentase kenaikan proses pembelajaran guru kelas V dan VI Semester 1 SD Negeri 2 Jobokuto Kecamatan Jepara Kabupaten Jepara Tahun Pelajaran 2019/2020 setelah melalui pembimbingan partisipasi aktif oleh kepala sekolah, dan 3)Mendekripsikan efektifitas pembimbingan partisipasi aktif kepala sekolah dalam meningkatkan kualitas pembelajaran guru kelas V dan VI Semester 1 SD Negeri 2 Jobokuto Kecamatan Jepara Kabupaten Jepara Tahun Pelajaran 2019/2020.

\section{Metode Penelitian}

Metode yang digunakan dalam dalam penelitian ini yaitu metode penelitian tindakan sekolah dalam dua siklus pembelajaran yang masing- masing melalui empat tahap yaitu: 1) perencanaan, 2) pelaksanaan, 3) pengamatan, 4) refleksi. Waktu penelitian yaitu bulan Juli sampai dengan bulan Desember 2019. Penelitian dilaksanakan di SD Negeri 2 Jobokuto Kecamatan Jepara Kabupaten Jepara. Subjek penelitian adalah guru kelas Vdan guru kelas VI SD Negeri 2 Jobokuto Jepara. Subjek penelitian yaitu guru kelas V dan VI. Data ini diambil pada akhir pelaksanaan Siklus I maupun akhir Siklus II. Sumber data diambil dari rata-rata skor lembar pengamatan yang diisi oleh kepala sekolah tentang tindakan pembimbingan dengan partisipasi aktif kepala sekolah yang penulis lakukan untuk guru kelas V dan VI setiap siklusnya.

Tehnik pengumpulan data menggunakan teknik non tes yaitu dengan pengamatan atau observasi. Data kualitas pembelajaran dan tindakan pembimbingan dengan partisipasi aktif kepala sekolah dikumpulkan dengan alat bantu yaitu lembar pengamatan. Data divalidasi dengan menggunakan proses triangulasi atau validasi data dilakukan dengan mencocokkan data lebih dari satu sumber. Data kualitas pembelajaran yang diperoleh melalui pengamatan oleh peneliti terhadap guru, divalidasi dengan data yang diperoleh dari pengamatan oleh kepala sekolah. Data hasil pembimbingan dengan partisipasi aktif kepala sekolah yang diperoleh dari pengamatan kolaborator yaitu kepala sekolah terhadap peneliti, kemudian divalidasi melalui hasil pengamatan yang dilakukan oleh guru yang diteliti, data kemudian dirata-rata.

Data dianalisis menggunakan cara dengan membandingkan antar skor data awal, data akhir Siklus I dan II. Jika data kualitas pembelajaran meningkat, berarti tindakan pembimbingan dengan partisipasi aktif kepala sekolah berperan dalam meningkatkan kualitas pembelajaran di SD Negeri 2 Jobokuto Jepara. Keberhasilan pembimbingan dapat diketahui dengan meningkatnya skor data pengamatan proses pembimbingan akhir Siklus II dibanding Siklus I. Indikator keberhasilan penelitian tindakan sekolah ini adalah sebagaimana berikut: Naiknya skor pengamatan kualitas pembelajaran guru dari kondisi awal $>40 \%$, dan naiknya skor pengamatan pembimbingan partisipasi aktif kepala sekolah dari kondisi awal $>75 \%$ serta tercapainya pembelajaran yang efektif. 


\section{Hasi Penelitian}

Hasil Penelitian Deskripsi hasil pemantauan kondisi awal yang dilakukan oleh penulis sebagai kepala SD Negeri 2 Jobokuto Kecamatan Jepara Kabupaten Jepara kepada guru kelas V dan VI sebagai berikut. Nilai rata-rata skor untuk guru kelas V adalah 1,12 dan guru kelas VI adalah 1,18 dengan rerata 1,15 dengan maksimal skor 3 atau skor maksimal,berarti pembelajaran belum dilaksanakan dengan baik. Kondisi awal sebelum dilaksanan bimbingan partisipasi aktif, Guru mengajar menggunakan buku teks yang dimiliki tanpa memperhatikan silabus dan RPP. Guru menerapkan metode ceramah dan tugas mengerjakan soal saja. terdapat guru yang belum menggunakan alat peraga dalam pembelajaran. Guru belum memanfaatkan multimedia komputer dalam kegiatan pembelajaran. Interaksi antar siswa tidak nampak sama sekali. Demikian juga dengan remidi dan pengayaan, sama sekali belum tampak. Salah satu solusi yang dikembangkan dengan pembimbingan melalui partisipasi aktif oleh kepala sekolah. Melalui pembimbingan secara aktif diharapkan kualitas pembelajaran meningkat.

Hasil observasi siklus I meliputi observasi guru dalam proses pembelajaran serta observasi kepala sekolah terhadap peneliti dalam melaksanakan tindakan pembimbingan. Hasil rata-rata penilaian kualitas proses pembelajaran yang dilakukan guru kelas $\mathrm{V}$ dan guru kelas VI di SDN Jobokuto sebagai berikut. Skor kualitas pembelajaran guru kelas V adalah 2,15 dan guru kelas VI adalah 2,18 dan rata-ratanya adalah 2,15 atau masih kurang maksimal (kurang memuaskan). Sedangkan hasil dari observasi proses membimbing dengan partisipasi aktif oleh kepala sekolah diperoleh skor pembimbingan untuk guru kelas V dan VI sama yaitu 2,10. Setelah divalidasi dengan data dari guru kelas V dan VI, maka rata-ratanya 2 atau kurang maksimal. Jika dibandingkan hasil observasi pada akhir Siklus I dengan data awal mengalami peningkatan dapat dilihat pada table berikut.

Tabel 1. Kualitas pembelajaran dan Pembimbingan dari Kondisi Awal ke Siklus I

\begin{tabular}{clcccc}
\hline No & Data Penelitian & Data Awal & Siklus I & Kenaikan & $\begin{array}{c}\text { Persentase } \\
\text { Kenaikan }\end{array}$ \\
\hline 1 & $\begin{array}{l}\text { Kualitas } \\
\text { Pembelajaran }\end{array}$ & 1,15 & 2,15 & 1,01 & $87 \%$ \\
2 & Pembimbingan & 0,0 & 2,06 & 2,06 & $68,67 \%$ \\
\hline
\end{tabular}

Berdasarkan tabel tersebut dapat diketahui bahwa kualitas pembelajaran mengalami kenaikan 1,01\% (87\%), dan pembimbingan terhadap kondisi awal mengalami peningkatan $2,06(68,67)$ dengan kerteria memenuhi. Berdasarkan hasil observasi menunjukkan bahwa proses pembelajaran belum nampak kegitan elaborasi dan konfirmasi. Sedangkan untuk pembimbingan masih belum nampak pada pembimbingan pada evaluasi pembelajaran, penyampaian tujuan, penggunaan variasi metode, memunculkan ide-ide kreatif guru.

Berdasarkan hasil refleksi siklus I siklus, maka proses pembimbingan akan dilanjutkan kesiklus Ke II diharapkan kualitas pembelajaran akan meningkat optimal. Berdasarkan tindakan siklus II menunjukan hasil yang maksimal, yang ditunjukkan adanya peningkatan mulai Siklus I sampai Siklus II. Peningkatan kualitas pembelajaran 2,15 meningkat menjadi 2,94 ada peningkatan 0,79 (37\%), sedangkan proses pembimbingan dari 2,06 meningkat menjadi 2,875 ada peningkatan 0,815 (27\%). Peningkatan rata-rata siklus I dan siklus II dapat dijelaskan dalam tabel berikut. 
Tabel 2. Peningkatan kualitas pembelajaran dan Pembimbingan dari Siklus I ke Siklus II

\begin{tabular}{clcccc}
\hline No & Data Penelitian & Siklus I & Siklus II & Kenaikan & $\begin{array}{c}\text { Persentase } \\
\text { Kenaikan }\end{array}$ \\
\hline 1 & $\begin{array}{l}\text { Kualitas } \\
\text { Pembelajaran }\end{array}$ & 2,15 & 2,94 & 0,79 & $37 \%$ \\
2 & Pembimbingan & 2,06 & 2,875 & 0,815 & $27 \%$ \\
\hline
\end{tabular}

Hasil dari refleksi antara penulis dan kolaborator nampak sudah dilaksanakan dengan dengan sangat baik, sehingga tidak melanjutkan ke siklus berikutnya.

\section{Pembahasan}

Berdasarkan hasil analisis dari kondisi awal dan setelah dilakukan tindakan perbaikan pada siklus Siklus I dan II dapat diketahui ada peningkatan kualitas pembelajaran dan pembimbingan kepada guru kelas V dan kelas VI SD Negeri Jobokuto Kabupaten Jepara pada semester I tahun pelajaran 2019/2020 mengalami peningkatan. Berikut merupakan perbandingan peningkatannya nilai rata-rata yang diperoleh pada kondisi awal ke siklus II.

Tabel 3. Data Penelitian Kondisi Awal, Siklus I, Siklus II

\begin{tabular}{|c|c|c|c|c|c|c|}
\hline No & Data Penelitian & $\begin{array}{l}\text { Data } \\
\text { Awal }\end{array}$ & Siklus I & Siklus II & Kenaikan & $\begin{array}{c}\text { Persentase } \\
\text { Kenaikan }\end{array}$ \\
\hline 1 & $\begin{array}{l}\text { Kualitas } \\
\text { Pembelajaran }\end{array}$ & 1,15 & 2,15 & 2,94 & 1,79 & $60 \%$ \\
\hline 2 & Pembimbingan & 0 & 2,06 & 2,875 & 2,875 & $96 \%$ \\
\hline
\end{tabular}

Berdasarkan tabel di atas setelah dibandingkan dari kondisi awal ke siklus II kualitas pembelajaran dari 1,15 menjadi 2,94 peningkatan sebesar 1,79 (60\%). Sedangkan pembimbingan juga mengalami peningkatan dari 2,06 menjadi sampai siklus II adalah $2,875(96 \%)$.

Hal ini terbukti bahwa guru kelas V dan VI setelah dilaksanakan pembimbingan partispasi aktif, hipotesis tindakan yang menyataan "Meningkatkan kualitas pembelajaran guru kelas V dan VI melalui pembimbingan partisipasi aktif kepala sekolah di SD Negeri 2 Jobokuto Kecamatan Jepara Kabupaten Jepara Tahun Pelajaran 2019/2020” dapat diterima. Penelitian yang serupa juga pernah dilaksanakan oleh Sarifudin (2019) yang menyatakan bahwa kepala sekolah sebagai bagian dari supervise pendidikan bertugas untuk membina guru agar menjadi guru yang professional dengan memberikan bimbingan berkaitan dengan penggunaan model, metode serta media pembelajaran yang sesuai untuk diterapkan pada kelas.

\section{Simpulan dan Saran}

Simpulan yang diambil setelah dilaksanakan penelitian selama dua siklus, dapat disimpulkan denganmelalui pembimbingan partisipasi aktif kepala sekolah dapat 
meningkatkan kualitas pembelajaran guru kelas V dan VI SD Negeri 2 Jobokuto Kecamatan Jepara Kabupaten Jepara tahun pelajaran 2019/2020. Dari hasil penelitian diperoleh peningkatan dari 1,15 pada kondisi awal menjadi 2,15, dalam siklus I, serta meningkat optimal menjadi 2,94 pada siklus II.

Disamping itu, terjadi kenaikan persentase proses pembimbingan dengan partisipasi aktif kepala sekolah dari kondisi awal belum dilaksanakan (0), menjadi dilaksanakan dengan skor keberhasilan 2,06 pada Siklus I dan 2,875 pada Siklus II sehingga total persentase kenaikan sebesar $96 \%$. Dengan demikian juga pembimbingan melalui partisipasi aktif efektif untuk meningkatkan kualitas pembelajaran guru kelas V dan VI Semester 1 SD Negeri 2 Jobokuto Kecamatan Jepara Kabupaten Jepara Tahun Pelajaran 2019/2020. Berdasarkan simpulan penulis mengajukan saran kepada guru agar selalu ikut aktif dalam pembimbingan serta aktif mengikuti kegiatan kelompok kerja guru (KKG). Saran bagi kepala sekolah agar menciptakan sekolah yang konduksif untuk mewujudkan sekolah yang efektif.

\section{Daftar Rujukan}

Arikunto, S. (1993). Manajemen Pengajaran Secara Manusiawi. Jakarta: Rineka Cipta.

Bafadal, I. (2003). Manajemen Peningkatan Kualitas Sekolah Dasar. Jakarta: Bumi Aksara. Budiarsih, Dyah. (2008). Laporan PTS, Meningkatkan Kemampuan Guru dalam Membuat dan Menggunakan Alat Peraga Melalui Pemberian Contoh.

Cullen, Jack., Len D'Innocenzo, (terjemahan). (2004). Memaksimalkan Kinerja. Yogyakarta: Tugu Publisher.

Depdiknas. (1993). Pedoman Bimbingan Guru dalam Kegiatan Belajar Mengajar. Jakarta: Dirjendikdasmen.

Hagemann, G. (1993). Motivasi untuk Pembinaan Organisasi. Jakarta: PT Pustaka Binaman.

Pressindo. Hamalik, O. (2001). Kurikulum dan Pembelajaran. Jakarta: Bumi Aksara. Juliantoro,

Mohamad Juliantoro. (2017). Peran Kepala Sekolah dalam Meningkatkan Kualitas Pendidikan. Jurnal al-Hikmah Kependidikan dan Syariah STAIBA, volume 5(2), hal: 24-38. http://jurnal.staiba.ac.id/index.php/Al-Hikmah/article/view/42/40

Keputusan Mendiknas Nomor 41 Tahun 2007 tentang Standar Proses untuk Satuan Pendidikan Dasar dan Menengah.

Kholis, Nur dkk. (2014). Kualitas Sekolah dan Budaya Partisipasi Stakeholders: Studi Fenomenologi di Sekolah Konfesional MIN Tegalasri Wlingi Blitar. Jurnal Pembangunan Pendidikan, volume 2(2), hal: 130-148. https://journal.uny.ac.id/index.php/jppfa/article/view/2639/2194

Sarifudin. (2019). Implementasi Supervisi Kepala Sekolah terhadap Kinerja Guru Dalam Upaya Meningkatkan Kualitas Pembelajaran di Madrasah Ibtidaiyah Negeri (MIN) Kota Bogor. Jurnal Manajemen Pendidikan Islam STAI Al-Hidayah Bogor, volume 2(1), hal: 49-70. http://jurnal.staialhidayahbogor.ac.id/index.php/jim/article/view/374

Sudibyo AP, Drs., M.Pd, (2007). Peningkatan Kinerja Guru Mata Pelajaran Ekonomi dalam Pengelolaan Pembelajaran Melalui Supervisi Individual Pendekatan Kolaboratif, Dinas Pendidikan Pemerintah Kota Semarang, Semarang. Laporan Penelitian Tindakan Sekolah 